\title{
Oestradiol-induced Infection of the Genital Tract of Female Mice by Mycoplasma hominis
}

\author{
By PATRICIA M. FURR AND DAVID TAYLOR-ROBINSON* \\ Division of Sexually Transmitted Diseases, Clinical Research Centre, Watford Road, Harrow, \\ Middlesex HAI 3UJ, UK
}

(Received 21 April 1989; revised 24 June 1989; accepted 29 June 1989)

Treatment of female BALB/c mice with oestradiol rendered them susceptible to vaginal colonization by three of four different strains of Mycoplasma hominis. Overall, the organisms were recovered persistently from the vagina of $68(87 \%)$ of 78 of these mice. Strain TO mice given one of the strains were at least as susceptible, all of ten becoming colonized and larger numbers of organisms being recovered. The hormone arrested the reproductive cycle in the oestrous phase, characterized by non-nucleated, cornified vaginal epithelial cells. In contrast, $M$. hominis organisms were isolated transiently from only seven $(10.5 \%)$ of $66 \mathrm{BALB} / \mathrm{c}$ mice not treated with oestradiol, after intravaginal inoculation; treatment with progesterone, which induced the dioestrous phase of the cycle, did not render any of $10 \mathrm{BALB} / \mathrm{c}$ mice susceptible to vaginal colonization. The minimum number of organisms $\left(2.5 \times 10^{5}\right)$ of one strain of $M$. hominis and the minimum dose of oestradiol $(0.05 \mathrm{mg})$ required to induce persistent colonization were established. Vaginal colonization persisted for more than $200 \mathrm{~d}$ in some mice, the numbers of organisms recovered ranging between $10^{1}$ and $10^{8}$. At autopsy there was evidence of spread to the uterine horns and ovaries, and also to the oropharynx, of some animals but not to other organs. Infection was not associated with a polymorphonuclear leucocyte response in the vagina or elsewhere, but a fourfold serum antibody response to $M$. hominis, measured by the metabolism-inhibition technique, was detected in almost half of the mice tested.

\section{INTRODUCTION}

A large-colony-forming mycoplasma was reported to have been isolated from a Bartholin's gland abscess in 1937 (Dienes \& Edsall, 1937). Considered in retrospect, this seems likely to have been Mycoplasma hominis and was the first mycoplasma to be recovered from the human species. Subsequently, it has been implicated in several conditions of the female genital tract, namely bacterial vaginosis, pelvic inflammatory disease, preterm labour and postpartum fever (Taylor-Robinson \& Munday, 1988), although its causal role has not been substantiated in all. In addition, it has been associated with postpartum arthritis, neonatal pneumonia and meningitis (Taylor-Robinson \& Munday, 1988) and various lesions in immunocompromised patients (Taylor-Robinson et al., 1986).

Small animal models of genital-tract infection by $M$. hominis have not been developed hitherto, because it has not been possible to establish mucosal colonization. However, treatment of female mice with progesterone enhanced infection of the genital tract by Mycoplasma pulmonis (Furr \& Taylor-Robinson, 1984; Taylor-Robinson \& Furr, 1985) and also by Chlamydia trachomatis (Tuffrey \& Taylor-Robinson, 1981). In contrast, such treatment has no enhancing effect on murine infection by Ureaplasma urealyticum, but this micro-organism has been induced to infect the genital tract of mice by treating them with oestradiol (Iwasaka et al., 1986; Furr \& Taylor-Robinson, 1989). These observations led us to investigate whether these sex hormones stimulate infection of the genital tract of female mice by strains of $M$. hominis. The use of oestradiol was found to be a crucial factor in initiating and maintaining infection.

Abbreviation: PMNL, polymorphonuclear leucocyte. 


\section{METHODS}

Mice. Young adult female mice, $8-10$ weeks of age, were used. They were strains BALB/c or TO and were bred in the specific pathogen-free unit at the Clinical Research Centre. They were mycoplasma-free before use.

Hormone treatment. Unless otherwise stated, oestradiol benzoate (Paines \& Byrne, Greenford, UK) was administered as a $0.5 \mathrm{mg}$ dose subcutaneously $(0.1 \mathrm{ml})$ on four occasions at weekly intervals. Smaller doses were prepared by diluting in ethyl oleate donated by Paines \& Byrne. Progesterone was given as described previously (Furr \& Taylor-Robinson, 1984).

Medium. Liquid medium used for culturing $M$. hominis organisms and for isolating them from the mice has been described previously (Manchee \& Taylor-Robinson, 1968). Briefly, it comprised beef heart infusion broth enriched with $20 \%(\mathrm{v} / \mathrm{v})$ horse serum and $10 \%(\mathrm{v} / \mathrm{v}) 25 \%(\mathrm{w} / \mathrm{v})$ yeast extract and supplemented with $0.1 \%$ L-arginine hydrochloride. The medium also contained 1000 i.u. penicillin $\mathrm{G} \mathrm{ml}^{-1}, 0.05 \%$ thallium acetate and $0.002 \%$ phenol red.

Inocula and inoculation. Four strains of M. hominis were used as follows. Strain MY11589 had been isolated from the urethra of a male patient with hypogammaglobulinaemia; it received two further subcultures and the culture for use contained $5 \times 10^{7}$ colour-changing units (c.c.u.; see below) $\mathrm{ml}^{-1}$. Strain MY17288 was received from the Public Health Laboratory, Norwich, UK, having been isolated from the blood of a patient with postpartum fever; it had been subcultured three times and the culture for use contained $5 \times 10^{8}$ c.c.u. Strain MY17378 had been isolated from a Caesarian incision of a patient with postpartum sepsis; it received two further subcultures and the culture for use contained $5 \times 10^{9}$ c.c.u. Strain PG21 was the type strain which had been subcultured repeatedly; the culture for use contained $5 \times 10^{8}$ c.c.u.

Each mouse received an inoculum of $50 \mu \mathrm{l}$ which was introduced into the vagina with an Eppendorf pipette at a time that coincided with the second dose of oestradiol.

Vaginal cytology. A nasopharyngeal swab (Medical Wire \& Equipment Co., Corsham, Wilts., UK) was inserted into the vagina of the mouse, rotated and then rolled along a 3 in $\times 1$ in glass slide. The smear was fixed in methanol for $30 \mathrm{~min}$ and then stained with Giemsa. The phase of the reproductive cycle was determined by assessing the presence or absence of polymorphonuclear leucocytes (PMNL) and nucleated and cornified squamous epithelial cells (Rugh, 1968).

Culture and identification procedure. The remaining contents of the vaginal swab were expressed in $1.8 \mathrm{ml}$ of liquid medium contained in a screw-capped glass vial of $2.5 \mathrm{ml}$ capacity. This was regarded as a $10^{-1}$ dilution and further tenfold dilutions were made serially to $10^{-8}$. At autopsy, organs were removed and portions homogenized to prepare $10 \%(\mathrm{w} / \mathrm{v})$ suspensions in medium; these were diluted to $10^{-4}$. Presumptive growth of $M$. hominis was indicated by a change in the colour of the medium from yellow to pink. The last dilution at which a colour change occurred was deemed to contain 1 colour-changing unit (c.c.u.) of $M$. hominis. Some isolates were identified definitively in a growth-inhibition test on agar medium (Clyde, 1964) with antiserum to $M$. hominis.

Measurement of antibody. Antibody to $M$. hominis was sought in sera and vaginal washings. A washing was obtained by introducing $50 \mu \mathrm{l}$ Dulbecco's phosphate-buffered saline into the vagina using an Eppendorf pipette, reintroducing the fluid and withdrawing it. Sera and washings were inactivated at $56^{\circ} \mathrm{C}$ for $30 \mathrm{~min}$ before being tested by the metabolism-inhibition technique (Purcell et al., 1966) using strain MY17288 of M. hominis.

\section{RESULTS}

\section{Effect of treating $B A L B / c$ mice with progesterone or oestradiol on their colonization by $M$. hominis}

Mycoplasmas were sought in the vagina by culture at about weekly intervals up to 13 weeks after intravaginal inoculation of $2.5 \times 10^{8}$ organisms of strain MY17378. Of 10 mice not treated with hormones, mycoplasmas were isolated from only two, in one case for less than $14 \mathrm{~d}$. They were not recovered from any of 10 mice treated with progesterone. In contrast, all 10 mice treated with oestradiol were colonized, mycoplasmas being recovered from eight of them for at least 13 weeks, and in half of these the number of mycoplasmas isolated at this time was similar to the number inoculated.

\section{Infectivity of different strains of $M$. hominis for oestradiol-treated $B A L B / c$ mice}

Four different strains of $M$. hominis were each introduced into the vagina of oestradiol-treated and untreated mice (Table 1) and were then sought as indicated previously. Strain MY17288, a blood isolate, colonized all 10 oestradiol-treated mice inoculated, and persisted in some of them for at least $200 \mathrm{~d}$. Strain MY17378, an abdominal incision isolate, behaved similarly. Strain MY11589, an urethral isolate, appeared to be less infectious, being recovered from only six of 10 
Table 1. Infectivity of different strains of $M$. hominis for oestradiol-treated and untreated $B A L B / c$ mice

\begin{tabular}{|c|c|c|c|c|c|c|c|}
\hline \multirow{2}{*}{$\begin{array}{l}\text { Mycoplasma } \\
\text { strain and } \\
\text { inoculum size }\end{array}$} & \multirow{2}{*}{$\begin{array}{l}\text { Oestradiol } \\
\text { treatment }\end{array}$} & \multicolumn{6}{|c|}{$\begin{array}{l}\text { No. of mice in groups of ten colonized } \\
\text { (and } \log _{10} \text { geometric mean titre) on day: }\end{array}$} \\
\hline & & 7 & 14 & 21 & 56 & 92 & 200 \\
\hline \multirow[t]{2}{*}{$\begin{array}{r}\text { MY17288 } \\
2.5 \times 10^{7}\end{array}$} & + & $\begin{array}{c}10 \\
(6 \cdot 6)\end{array}$ & $\begin{array}{c}10 \\
(6 \cdot 1)\end{array}$ & $\begin{array}{c}10 \\
(5 \cdot 1)\end{array}$ & $\begin{array}{r}7 * \\
(5 \cdot 2)\end{array}$ & $\begin{array}{c}6 \dagger \\
(6 \cdot 5)\end{array}$ & $\begin{array}{r}5 \dagger \\
(5 \cdot 6)\end{array}$ \\
\hline & - & $\begin{array}{r}2 \\
(0.9)\end{array}$ & $\begin{array}{c}1 \\
(0 \cdot 6)\end{array}$ & 0 & $\mathrm{NT}$ & NT & NT \\
\hline \multirow[t]{2}{*}{$\begin{array}{r}\text { MY17378 } \\
2.5 \times 10^{8}\end{array}$} & + & $\begin{array}{c}10 \\
(7 \cdot 1)\end{array}$ & $\begin{array}{c}10 \\
(6 \cdot 4)\end{array}$ & $\begin{array}{c}10 \\
(6 \cdot 6)\end{array}$ & $\begin{array}{c}8 \\
(4 \cdot 9)\end{array}$ & $\begin{array}{c}8 \\
(4 \cdot 3)\end{array}$ & NT \\
\hline & - & $\begin{array}{c}2 \\
(1 \cdot 3)\end{array}$ & 0 & $\begin{array}{c}1 \\
(0 \cdot 3)\end{array}$ & $\begin{array}{c}1 \\
(0 \cdot 5)\end{array}$ & $\begin{array}{c}1 \\
(0 \cdot 1)\end{array}$ & NT \\
\hline \multirow[t]{2}{*}{$\begin{array}{r}\text { MY11589 } \\
2.5 \times 10^{6}\end{array}$} & + & $\begin{array}{c}6 \\
(3 \cdot 2)\end{array}$ & $\begin{array}{r}5^{*} \\
(2 \cdot 7)\end{array}$ & $\begin{array}{r}4^{*} \\
(2 \cdot 3)\end{array}$ & $\begin{array}{r}3 \ddagger \\
(2 \cdot 0)\end{array}$ & NT & NT \\
\hline & - & $\begin{array}{c}1 \\
(0 \cdot 7)\end{array}$ & $\begin{array}{c}1 \\
(0 \cdot 7)\end{array}$ & 0 & NT & NT & NT \\
\hline \multirow[t]{2}{*}{$\begin{array}{l}\text { PG21 } \\
2.5 \times 10^{7}\end{array}$} & + & $\begin{array}{c}1 \\
(0 \cdot 4)\end{array}$ & 0 & NT & NT & NT & NT \\
\hline & - & 0 & 0 & NT & NT & NT & NT \\
\hline
\end{tabular}

NT, Not tested.

* Of nine mice. $\quad$ OO six mice. $\quad \ddagger$ Of seven mice.

Table 2. Infectivity of $M$. hominis for oestradiol-treated and untreated BALB/c and TO mice

$M$. hominis MY17288 (2.5 $\times 10^{7}$ c.c.u.) was the strain used.

No. of mice in groups of ten colonized

(and $\log _{10}$ geometric mean titre) on day:

\begin{tabular}{|c|c|c|c|c|c|c|c|c|c|}
\hline \multirow{2}{*}{$\begin{array}{l}\text { Mouse } \\
\text { strain }\end{array}$} & \multirow{2}{*}{$\begin{array}{l}\text { Oestradiol } \\
\text { treatment }\end{array}$} & \\
\hline & & 7 & 14 & 21 & 35 & 56 & 92 & 200 & 255 \\
\hline $\mathrm{BALB} / \mathrm{c}$ & + & $\begin{array}{c}10 \\
(6 \cdot 6)\end{array}$ & $\begin{array}{c}10 \\
(6 \cdot 1)\end{array}$ & $\begin{array}{c}10 \\
(5 \cdot 1)\end{array}$ & $\begin{array}{c}9 \\
(4 \cdot 7)\end{array}$ & $\begin{array}{c}7^{*} \\
(5 \cdot 2)\end{array}$ & $\begin{array}{c}6 \dagger \\
(6.5)\end{array}$ & $\begin{array}{c}5 \dagger \\
(5.6)\end{array}$ & NT \\
\hline & - & $\begin{array}{c}2 \\
(0.9)\end{array}$ & $\begin{array}{c}1 \\
(0 \cdot 6)\end{array}$ & 0 & NT & $\mathrm{NT}$ & $\mathrm{NT}$ & NT & NT \\
\hline To & + & $\begin{array}{c}10 \\
(6.9)\end{array}$ & $\begin{array}{c}10 \\
(7 \cdot 0)\end{array}$ & $\begin{array}{c}10 \\
(7 \cdot 3)\end{array}$ & $\begin{array}{c}10 \\
(7 \cdot 4)\end{array}$ & NT & $\begin{array}{c}9^{*} \\
(7 \cdot 7)\end{array}$ & $\begin{array}{r}6 \ddagger \\
(5 \cdot 0)\end{array}$ & $\begin{array}{r}6 \S \\
(5 \cdot 1)\end{array}$ \\
\hline & - & $\begin{array}{c}1 \\
(0 \cdot 4)\end{array}$ & 0 & 0 & NT & NT & $\mathrm{NT}$ & NT & $\mathrm{NT}$ \\
\hline
\end{tabular}

NT, Not tested.

* Of nine mice. † $\quad$ Of six mice. $\quad \ddagger$ Of eight mice. $\$$ Of seven mice.

oestradiol-treated mice and from only three of these after $56 \mathrm{~d}$. However, the mice received 10-fold fewer organisms than those given the blood isolate. The reference strain (PG21) was not infectious, being isolated transiently from only one of 10 oestradiol-treated mice despite the fact that they received the same number of organisms as mice inoculated with the blood isolate. The number of organisms, of any of the strains, recovered at termination of the experiments was usually similar to the number inoculated. Only five of 40 untreated control mice were colonized by $M$. hominis and only one for longer than $14 \mathrm{~d}$.

\section{Susceptibility of two different strains of oestradiol-treated mice to $M$. hominis}

Groups of BALB/c and TO mice were each inoculated intravaginally with $2.5 \times 10^{7}$ c.c.u. of the MY17288 strain of $M$. hominis (Table 2). Organisms were recovered only transiently from a few of the untreated mice, but they were isolated consistently from all of the oestradiol-treated mice. Larger numbers of organisms were recovered from the TO mice, but otherwise the pattern 
Table 3. Response of oestradiol-treated and untreated $B A L B / c$ mice to inocula containing different numbers of $M$. hominis organisms

M. hominis strain MY17288 was used.

\begin{tabular}{|c|c|c|c|c|c|c|c|c|}
\hline \multirow{2}{*}{$\begin{array}{c}\text { No. of } \\
\text { organisms } \\
\text { inoculated } \\
\text { (c.c.u.) }\end{array}$} & \multirow{2}{*}{$\begin{array}{l}\text { Oestradiol } \\
\text { treatment }\end{array}$} & \multicolumn{7}{|c|}{$\begin{array}{l}\text { No. of mice in groups of ten colonized } \\
\text { (and } \log _{10} \text { geometric mean titre) on day: }\end{array}$} \\
\hline & & 7 & 14 & 21 & 28 & 35 & 56 & 106 \\
\hline \multirow[t]{2}{*}{$2.5 \times 10^{1}$} & + & 0 & $\begin{array}{c}1 \\
(0 \cdot 1)\end{array}$ & 0 & 0 & NT & NT & NT \\
\hline & - & 0 & 0 & NT & NT & NT & NT & NT \\
\hline \multirow[t]{2}{*}{$2.5 \times 10^{3}$} & + & $\begin{array}{c}9 \\
(5 \cdot 2)\end{array}$ & $\begin{array}{c}9 \\
(2 \cdot 7)\end{array}$ & $\begin{array}{c}9 \\
(2 \cdot 7)\end{array}$ & $\begin{array}{c}5 \\
(2 \cdot 0)\end{array}$ & $\begin{array}{c}2^{*} \\
(0 \cdot 2)\end{array}$ & $\begin{array}{c}1^{*} \\
(0 \cdot 1)\end{array}$ & $0^{*}$ \\
\hline & - & $\begin{array}{c}1 \\
(0 \cdot 5)\end{array}$ & 0 & NT & NT & NT & NT & NT \\
\hline \multirow[t]{2}{*}{$2.5 \times 10^{5}$} & + & $\begin{array}{c}9 \\
(6 \cdot 0)\end{array}$ & $\begin{array}{c}8 \\
(4 \cdot 0)\end{array}$ & $\begin{array}{c}8 \\
(4 \cdot 7)\end{array}$ & $\begin{array}{c}8 \\
(4.4)\end{array}$ & $\begin{array}{c}6 \\
(3.8)\end{array}$ & $\begin{array}{c}5 \\
(3 \cdot 2)\end{array}$ & $\begin{array}{c}2 \\
(1 \cdot 4)\end{array}$ \\
\hline & - & $\begin{array}{c}1 \\
(0 \cdot 3)\end{array}$ & 0 & NT & $\mathrm{NT}$ & NT & $\mathrm{NT}$ & $\mathrm{NT}$ \\
\hline \multirow[t]{2}{*}{$2.5 \times 10^{7}$} & + & $\stackrel{9}{9}$ & $\begin{array}{c}8 \\
(4 \cdot 9)\end{array}$ & $\begin{array}{c}9 \\
(5 \cdot 6)\end{array}$ & $\begin{array}{c}8 \\
(5 \cdot 8)\end{array}$ & $\begin{array}{c}8 \\
(5 \cdot 1)\end{array}$ & $\begin{array}{c}6 \\
(3 \cdot 0)\end{array}$ & $\begin{array}{c}4 \\
(2 \cdot 2)\end{array}$ \\
\hline & - & 0 & 0 & NT & NT & NT & NT & NT \\
\hline
\end{tabular}

Table 4. Response of BALB/c mice to $M$. hominis after treatment with different concentrations of oestradiol

M. hominis strain MY17288 was used.

No. of mice in groups of six colonized

Oestradiol concn

(mg per $0 \cdot 1 \mathrm{ml}$ )

(and $\log _{10}$ geometric mean titre) on day:

\begin{tabular}{cccccc}
0.5 & 5 & 5 & $4^{*}$ & $4^{*}$ & 5 \\
& $(4 \cdot 8)$ & $(4 \cdot 3)$ & $(5 \cdot 0)$ & $(5 \cdot 0)$ & $(7 \cdot 2)$ \\
0.1 & 4 & 4 & 4 & 5 & NT \\
& $(7 \cdot 0)$ & $(6 \cdot 7)$ & $(6 \cdot 7)$ & $(5 \cdot 8)$ & \\
0.05 & 6 & 6 & 6 & 6 & NT \\
& $(5 \cdot 3)$ & $(5 \cdot 6)$ & $(6 \cdot 3)$ & $(6 \cdot 5)$ & \\
0.01 & 3 & $4^{*}$ & $2^{*}$ & $2^{*}$ & $1^{*}$ \\
& $(2 \cdot 6)$ & $(3 \cdot 2)$ & $(3 \cdot 3)$ & $(2 \cdot 8)$ & $(1 \cdot 2)$ \\
0.005 & 3 & $4^{*}$ & $3^{*}$ & $3^{*}$ & $0^{*}$ \\
& $(2 \cdot 2)$ & $(3 \cdot 2)$ & $(3 \cdot 4)$ & $(4 \cdot 0)$ & \\
Nil & 0 & 0 & 0 & 0 & NT \\
& \multicolumn{5}{c}{ NT, Not tested. } \\
& * Of five mice. & & \\
& & &
\end{tabular}

Table 5. Recovery of $M$. hominis from extra-vaginal anatomical sites

No. of mice from which organisms were recovered from:

$\begin{array}{ccc}\begin{array}{c}\text { Strain of } \\ \text { M. hominis }\end{array} & \begin{array}{c}\text { No. of } \\ \text { mice }\end{array} & \begin{array}{c}\text { Days after } \\ \text { inoculation }\end{array} \\ \text { MY17288 } & 7^{*} & 108 \\ \text { MY11589 } & 5 \dagger & 44 \\ & 3 & 34\end{array}$

$\begin{array}{ccccc}\text { Vagina } & \overbrace{\text { Right }}^{\text {Uterine horns }} & \text { Left } & \begin{array}{c}\text { Ovary } \\ \text { (Right) }\end{array} & \text { Throat } \\ 6 & 2 & 2 & 1 & 4 \\ 5 & 0 & 0 & 0 & 0 \\ 3 & 1 & 2 & 2 & 0\end{array}$

$-M$. hominis was isolated ( $\geqslant 10^{4}$ c.c.u.) from bladder urine of one of these mice. $\dagger$ Specimens from liver, spleen and kidney negative. 
of colonization in the two strains of mice was similar, the organisms persisting for at least 7-8 months.

\section{Minimal number of $M$. hominis organisms required for colonization}

A vaginal inoculum containing $2.5 \times 10^{1}$ organisms of strain MY17288 was insufficient to allow colonization of oestradiol-treated BALB/c mice (Table 3). An inoculum containing $2.5 \times 10^{3}$ organisms resulted in their recovery from nearly all such mice but after an initial increase in the number of organisms, the number isolated was small and few of the mice had organisms persisting after $28 \mathrm{~d}$. In contrast, $2.5 \times 10^{5}$ or more organisms resulted in colonization, large numbers being recovered from the mice for much longer. Hence, it appeared that about $10^{5}$ organisms was the minimal dose for effective colonization.

\section{Effect of treating $B A L B / C$ mice with different concentrations of oestradiol}

Treating mice with $0.05 \mathrm{mg}$ oestradiol (Table 4) resulted in no less colonization and persistence by $M$. hominis organisms (strain MY17288) than occurred after treating them with the usual concentration of oestradiol $(0.5 \mathrm{mg})$. Treatment with less oestradiol than $0.05 \mathrm{mg}$ resulted in the organisms being recovered from and persisting in a smaller proportion of animals, but even $0.005 \mathrm{mg}$ had some effect on enhancing susceptibility.

\section{Occurrence of $M$. hominis in extra-vaginal sites}

Twelve oestradiol-treated BALB/c mice, 11 of which were still colonized vaginally, were examined at autopsy 44 to $108 \mathrm{~d}$ after inoculation with strain MY17288 of $M$. hominis (blood isolate) (Table 5). The organisms were isolated from the upper genital tract of two of them and from the throat of four. Of three mice that were still colonized vaginally and autopsied $34 \mathrm{~d}$ after inoculation with strain MY11589 (urethral isolate), organisms were also recovered from the upper genital tract of two.

\section{Cytological changes}

Vaginal smears from 198 mice, 131 of which were treated with oestradiol and given $M$. hominis, were examined. All oestradiol-treated mice had their reproductive cycle arrested at the oestrous phase. This was characterized by non-nucleated epithelial cells and few or no PMNL. There was no increase in the number of leucocytes in the smears even when large numbers of $M$. hominis organisms were present or colonization was of long duration.

\section{Antibody responses}

Blood was taken from 25 oestradiol-treated BALB/c mice at autopsy $108 \mathrm{~d}$ after inoculation with strain MY17288 of $M$. hominis and tested for antibody to $M$. hominis. A fourfold rise in the titre of antibody (1/16 to 1/64) was detected in two of 10 mice given $2.5 \times 10^{7}$ c.c.u., in six of 10 mice given $2.5 \times 10^{5}$ c.c.u., but in none of five mice given $2.5 \times 10^{3}$ c.c.u. A further 10 mice that had been treated with oestradiol, but only five of which had been inoculated with strain MY17288 ( $2.5 \times 10^{7}$ c.c.u.), exhibited no evidence of an antibody response $44 \mathrm{~d}$ later. Antibody was not detected in the vaginal washings of any of the mice.

\section{DISCUSSION}

The results of previous studies showed that colonization of the genital tract of female mice by $M$. pulmonis was enhanced by treating the mice with progesterone (Furr \& Taylor-Robinson, 1984; Taylor-Robinson \& Furr, 1985), while colonization by ureaplasmas was dependent on treatment with oestradiol (Iwasaka et al., 1986; Furr \& Taylor-Robinson, 1989). There was no doubt that the vagina of mice that had not been treated with either hormone was refractory to colonization by $M$. hominis, because of 76 such BALB/c and TO mice inoculated intravaginally with $\geqslant 2.5 \times 10^{5}$ organisms, the mycoplasma was recovered from only eight, persisting longer than $14 \mathrm{~d}$ in only one. The intravaginal inoculation of untreated rats with $M$. hominis also failed to establish infection (Deodhar, 1988), although some pathological changes were interpreted to 
mean that a model of $M$. hominis-induced disease had been developed. In mice we have found no evidence that progesterone stimulates colonization by $M$. hominis organisms, since they were not recovered from any of ten mice $7 \mathrm{~d}$ after intravaginal inoculation or subsequently. In distinct contrast, of 88 mice, all but ten of which were of the BALB/c strain, that were treated with oestradiol $(\geqslant 0.05 \mathrm{mg})$ and then inoculated with $\geqslant 2.5 \times 10^{3}$ organisms, 78 became colonized, 74 of them for $21 \mathrm{~d}$ or longer. Indeed, recovery from some was achieved for $200 \mathrm{~d}$ or more and the number of organisms isolated was usually large $\left(\geqslant 10^{5}\right)$. In later experiments with graded doses of oestradiol, we found that colonization and persistence could be brought about by a dose $(0.05 \mathrm{mg})$ at least 10 -fold less than that used originally; indeed, even a 100 -fold smaller dose $(0.005 \mathrm{mg})$ had some stimulatory effect. Whether different strains of mice respond differently to $M$. hominis requires further investigation; the two strains examined seemed about equally susceptible in that all the mice became colonized but the numbers of organisms recovered from the TO strain were consistently larger. A vaginal PMNL response was not seen, possibly because it was abrogated by the hormone treatment, in which case any potential differences in the virulence of strains of $M$. hominis in terms of their ability to stimulate an inflammatory response would have been masked. However, a difference in virulence became apparent when we failed to colonize the mice with the multiply passaged type strain, even though the inoculum contained a large number of organisms. The minimal number of organisms required to establish colonization, determined for one strain of $M$. hominis, was at least 1000-fold less than that used in most experiments. This indicates clearly a potential means of determining differences between strains of $M$. hominis in terms of the number of organisms required to colonize and persist. The results of the current experiments have shown that the organisms spread beyond the lower genital tract in some mice. Whether, as seems likely, such invasiveness is a reflection of pathogenicity and varies among different strains is possible to determine only by examining a larger number of strains. The recovery of $M$. hominis organisms from the oropharynx of some mice probably reflects no more than 'contamination' arising from their presence in large numbers in the vagina rather than colonization in the oropharynx. It seems unlikely that oestrogen administration would influence susceptibility in this site directly.

However, this question and the mechanism underlying the oestradiol-induced susceptibility of the genital tract to $M$. hominis require investigation. The induced genital tract susceptibility could be simply a matter of the reproductive cycle being arrested in the oestrous phase, enabling the organisms to become attached to susceptible cells which remain in the tract. On the other hand, it is possible that oestrogen administration provides additional oestrogen receptors or cells to which the organisms adhere; alternatively, it might also allow multiplication of endogenous bacteria in the vagina and so produce an environment which is conducive to the growth and maintenance of $M$. hominis. Resolution of these problems should have a bearing not only on susceptibility to $M$. hominis, but also on the phenomenon of hormone-induced susceptibility to a range of micro-organisms in the genital tract of human and other species.

\section{REFERENCES}

CLYDE, W. A. (1964). Mycoplasma species identification based upon growth inhibition by specific antisera. Journal of Immunology 92, 958-965.

DEODHAR, L. (1988). Experimental uterine infection in rats with $M$. hominis. Journal of Postgraduate Medicine 34, 91-92.

Dienes, L. \& EdsalL, G. (1937). Observations on the L-organism of Klieneberger. Proceedings of the Society for Experimental Biology and Medicine 36, 740-744.

FURR, P. M. \& TAYLoR-Robinson, D. (1984). Enhancement of experimental Mycoplasma pulmonis infection of the mouse genital tract by progesterone treatment. Journal of Hygiene 92, 139-144.

FurR, P. M. \& TAYLOR-Robinson, D. (1989). The establishment and persistence of Ureaplasma urea- lyticum in oestradiol-treated female mice. Journal of Medical Microbiology 29, 111-114.

IWASAKA, T., WADA, T. \& SugImorI, H. (1986). Enhancement of colonization of Ureaplasma urealyticum in the mouse genital tract by estrogen treatment. American Journal of Obstetrics and Gynecology 155, 1124-1127.

MANCheE, R. J. \& TAYloR-Robinson, D. (1968). Haemadsorption and haemagglutination by mycoplasmas. Journal of General Microbiology 50, 465-478.

Purcell, R. H., Taylor-Robinson, D., Wong, D. C. \& ChANOCK, R. M. (1966). A color test for the measurement of antibody to the non-acid-forming human Mycoplasma species. American Journal of Epidemiology 84, 51-66. 
Rugh, R. (1968) (editor). The Mouse. Its Reproduction and Development, pp. 38-39. Minneapolis: Burgess . Publishing Co.

TAYlor-Robinson, D. \& Furr, P. M. (1985). The interplay of host and organism factors in infection of the mouse genital tract by Mycoplasma pulmonis. Journal of Hygiene 95, 7-14.

TAYLOR-RoBINSON, D. \& MUNDAY, P. E. (1988). Mycoplasmal infection of the female genital tract and its complications. In Genital Tract Infection in Women, pp. 228-247. Edited by M. J. Hare.
Edinburgh \& New York: Churchill Livingstone. TAYLOR-ROBInSON, D., FURR, P. M. \& Webster, A. D. B. (1986). Ureaplasma urealyticum in the immunocompromised host. Pediatric Infectious Disease 5, S 236-238.

TUFfrey, M. \& TAYLOR-Robinson, D. (1981). Progesterone as a key factor in the development of a mouse model for genital tract infection with Chlamydia trachomatis. FEMS Microbiology Letters 12, 111-115. 